\title{
BIEN JURÍDICO Y SANCIÓN PENAL EN EL DELITO DE OMISIÓN DEL DEBER DE SOCORRO
}

\author{
Miguel Bustos Rubio \\ Investigador de Doctorado en Derecho Penal \\ Universidad Complutense de Madrid \\ mbust01@ucm.es
}

\begin{abstract}
RESUMEN
El delito de omisión del deber de socorro recogido en el actual art. 195 del Código Penal es una de las figuras más tradicionales en nuestro Derecho penal, figura que ha generado desde antiguo una larga discusión doctrinal en torno a la determinación del bien jurídico que se pretende proteger. Desde la solidaridad bumana, hasta bienes individuales como la vida o la integridad física, pasando por la seguridad de las personas, en este articulo se ordenan esquemáticamente las principales opiniones doctrinales surgidas al respecto, con una toma de postura muy concreta que da paso al segundo nivel de discusión: ¿es correcta la pena que contempla el actual art. 195 del Código Penal? Desde una visión respetuosa con el principio de proporcionalidad y la igualdad, así como desde una comparativa sistemática con otros artículos del Código, se defiende una postura de lege ferenda que apueste por graduar las penas en este delito, dependiendo del concreto bien jurídico que se entienda afectado.
\end{abstract}

Palabras clave: Derecho penal, delitos de omisión, omisión del deber de socorro, bien jurídico, solidaridad, seguridad, proporcionalidad, sanción penal, igualdad, pena.

\section{ABSTRACT}

The crime of neglect of duty of assistance as it appears in the current article 195 of the Penal Code is one of the most traditional figures of Spanish Penal Law and it has long raised doctrinal controversy regarding the legal asset to be protected. Ranging from buman solidarity to individual assets such as life or physical integrity or people's safety we will arrange in this article an outline of the main clearly positioned doctrinal opinions regarding this subject, which takes us to the next debate: is it correct to apply the sentence seen in the current article 195 of the Penal Code? From an approach respectful with the principle of proportion/ proportionality and equality as well as in systematic comparison to other articles from the same code, we can support a position of lege ferenda based on grading such crime's sentences, depending on the particular legal asset affected.

Keywords: Penal Law, neglect of duty, neglect of duty of assistance, legal asset, solidarity, safety, proportionality, penal ban, equality, ban. 


\section{ZUSAMMENFASSUNG}

Die Straftat der unterlassenen Hilfeleistung ist im derzeitigen Artikel 195 des Strafgesetzbuchs erfasst und gebört zu einer der ältesten Rechtsfiguren unseres Strafgesetzbuchs. Diese Rechtsfigur hat von jeher eine lange Lebrdiskussion um das entsprechende Rechtsgut entfacht, das es zu schützen beabsichtigt. Von der menschlichen Solidarität bis bin zu individuellen Rechtsgütern: über das Recht auf Leben, das Recht auf körperliche Unversehrtheit hin zur Personensicherheit. In diesem Artikel werden schematisch die wichtigsten einschlägigen Lebrmeinungen zum Thema erfasst und es wird konkret Stellung bezogen, um dann auf einer zweiten Diskussionsebene zur Frage zu gelangen: Ist die im aktuellen Artikel 195 des Strafgesetzbuchs festgelegte Strafe angemessen? Von der Warte des Prinzips der Verbältnismäßigkeit und Gleichheit aus sowie aus der vergleichenden Systematik mit anderen Strafgesetzbuchartikeln wird der Standpunkt des lege ferenda vertreten, der vorsiebt, die Strafen dieser Straftat je nach betroffenem Rechtsgut zu staffeln.

Schlüsselwörter: Strafrecht, Straftatbestand der Unterlassung, Straftatbestand der unterlassenen Hilfeleistung, Rechtsgut, Solidarität, Sicherheit, Verhältnismäßigkeit, Strafsanktion, Gleichheit, Strafe.

SUMARIO: I. INTRODUCCIÓN.-II. DETERMINACIÓN DEL BIEN JURÍDICO PROTEGIDO POR EL DELITO DEL ART. 195 CP.-1. La importancia de delimitar el bien jurídico.-2. El bien jurídico protegido: principales posturas.-3.-Toma de postura.-III. PROPORCIONALIDAD Y SANCIÓN PENAL. PROPUESTA DE LEGE FERENDA.-IV. CONCLUSIONES.V. BIBLIOGRAFÍA.-VI. JURISPRUDENCIA CITADA.

\section{INTRODUCCIÓN}

El art. 195 del Código Penal español recoge el delito de omisión del deber de socorro, figura de amplia tradición en nuestro Derecho (y en el de los países de nuestro entorno) que antaño suscitó numerosas discusiones doctrinales. El apartado primero del citado artículo reza: «El que no socorriere a una persona que se halle desamparada y en peligro manifiesto y grave, cuando pudiere hacerlo sin riesgo propio ni de terceros, será castigado con la pena de multa de tres a doce meses». Por su parte, el apartado segundo contempla que: «En las mismas penas incurrirá el que, impedido de prestar socorro, no demande con urgencia auxilio ajeno».

En el presente artículo se abordarán dos cuestiones elementales en relación a este tipo penal. La primera de ellas, determinante como paso previo a la segunda, consistirá en dilucidar cuál es el interés objeto de tutela y protección por este delito, esto es, el bien jurídico que pretende salvaguardarse, cuestión que ha sido objeto de un amplio debate doctrinal. 
Una vez resuelta esta primera cuestión, en segundo lugar se procederá a analizar la sanción penal que contempla el actual tipo del art. 195 (en sus apartados primero y segundo). El análisis de este segundo punto necesariamente viene ligado a la postura que se adopte respecto del primero, esto es, depende de lo que se haya contestado a la pregunta de cuál es el bien jurídico tutelado, pues sólo teniendo claro esto último puede elaborarse después un juicio de valor sobre la pena que contempla el tipo penal objeto de análisis, juicio que se realizará desde la idea de «proporcionalidad» que debe existir entre la gravedad del hecho y la pena como consecuencia jurídico-penal.

\section{DETERMINACIÓN DEL BIEN JURÍDICO PROTEGIDO POR EL DELITO DEL ART. $195 \mathrm{CP}^{1}$}

\section{La importancia de delimitar el bien jurídico}

Partiendo de la idea de que toda norma penal, todo delito contemplado en el Código Penal, tiene una función protectora de un determinado bien jurídico, Muñoz Conde entiende por tal el valor que la ley quiere proteger de todas aquellas conductas que puedan dañarlo, siendo una cualidad que el legislador atribuye a determinados intereses. El bien jurídico como categoría dogmática está llamado a cumplir distintas funciones. Además de una función clasificadora, pues agrupa los distintos tipos delictivos en función del bien que protegen, el bien jurídico tiene la importante función de permitir conocer la naturaleza del delito, interpretar los elementos del tipo y proporcionar a éste sentido y fundamento ${ }^{2}$.

En este sentido, la postura que se tenga del bien jurídico protegido por este tipo penal será determinante a la hora de analizar algunos aspectos del

${ }^{1}$ Este epígrafe forma parte, en su gran mayoría y salvo algunas modificaciones, del trabajo de investigación que presenté en la Facultad de Derecho de la Universidad Complutense de Madrid como trabajo de fin de máster en junio de 2012. Vid. M. Bustos Rubio, La tipicidad objetiva en el delito de omisión del deber de socorro personal, Madrid, Servicio de Publicaciones de la Facultad de Derecho UCM, 2013.

${ }^{2}$ F. Muñoz Conde, Teoría general del delito, 4. ${ }^{\text {a }}$ ed., Valencia, Tirant lo Blanch, 2007, pp. 64-65. Sobre las cualidades del bien jurídico vid. F. Muñoz Conde y M. García ArÁn, Derecho penal, parte general, 8. ${ }^{a}$ ed. revisada y puesta al día, Valencia, Tirant lo Blanch, 2010, pp. 59 y ss. En el mismo sentido C. M. Landecho Velasco y C. Molina Blázquez, Derecho penal español. Parte general, 8. ${ }^{a}$ ed. actualizada conforme a la LO 5/2010, Madrid, Tecnos, 2010, pp. 254-255. Estos últimos autores destacan la importancia del bien jurídico como criterio interpretativo de los elementos del tipo. 
delito de omisión del deber de socorro ${ }^{3}$. Más concretamente, y en lo que a este artículo se refiere, la determinación del interés objeto de tutela es de suma importancia en base, como se verá infra, al análisis posterior sobre la sanción penal.

El punto de partida consiste, por tanto, en elaborar un primer análisis para determinar qué bien jurídico se protege con el tipo penal del art. 195 $\mathrm{CP}$, cuestión ésta que, como advierte Gómez Tomillo, es en todo grado controvertida, pues en pocas figuras delictivas se detecta mayor discusión sobre el bien jurídico que en el tipo penal de omisión del deber de soco$\mathrm{rro}^{4}$. A continuación se exponen las principales líneas doctrinales que se revelan ante la cuestión de determinación del bien jurídico protegido por el delito de omisión del deber de socorro del art. 195 CP.

\section{El bien jurídico protegido: principales posturas ${ }^{5}$}

\section{A. Teorías doctrinales en la determinación del bien jurídico protegido}

a) La solidaridad humana como bien jurídico directamente protegido

La omisión del deber de socorro aparece recogida por vez primera en el CP de 1822 en forma de delito ${ }^{6}$, para después convertirse, con el CP

${ }^{3}$ Por ejemplo, lo relativo al conocimiento de la figura del sujeto pasivo en tanto es titular del mismo, o aquellos casos en los cuales se quiera saber si el sujeto está o no legitimado para disponer del bien jurídico, pues sólo podrá disponer del mismo quien sea su titular. También cobra importancia al hablar de la «gravedad» que exige la situación de peligro descrita en el tipo penal; en definitiva, la cuestión de delimitación del bien jurídico constituye un punto de partida elemental para el estudio posterior de los elementos del tipo. En este sentido, J. J. Bustos Ramírez y N. Hormazábal Malarée, Nuevo sistema de Derecho penal, Madrid, Trotta, 2004, p. 73, entienden que «los dos momentos fundamentales del delito, esto es, la tipicidad y la antijuridicidad, tienen como condición necesaria, aunque no suficiente, el bien jurídico». Los autores consideran que tanto la tipicidad como la antijuridicidad vienen referidas al bien jurídico, de lo que se deriva la importancia de la determinación de éste. Para mayor abundamiento vid. M. Bustos Rubio, La tipicidad objetiva en el delito de omisión..., op. cit., pp. 31 y ss.

${ }^{4}$ M. Gómez Tomillo, El deber de socorro (art. 195.1 del Código Penal), Valencia, Tirant lo Blanch, 2003, p. 33.

${ }^{5} \mathrm{Si}$ bien la discusión acerca del interés jurídico tutelado por este delito ha proporcionado cuantiosos pronunciamientos doctrinales, en este artículo se recogen las líneas principales de manera esquemática.

${ }^{6}$ El CP de 9 de julio de 1822 tipificó el delito de omisión del deber de socorro en su art. 698, que rezaba lo siguiente: «Todo el que pudiendo hacerlo sin perjuicio ni riesgo suyo no prestare el socorro que esté en su arbitrio á cualquiera persona que halle herida, mal- 
de 1848 , en simple falta ${ }^{7}$. Tras su establecimiento en el ordenamiento jurídico, la figura sufrió algunas modificaciones en su redacción, llegando finalmente a un punto clave en la historia del tipo penal, cual es la aprobación de la Ley de 17 de julio de $1951^{8}$. Esta ley vino a poner de manifiesto la necesidad de un cambio en la redacción del tipo penal de omisión del deber de socorro, dada la insuficiencia de los preceptos de anteriores Códigos. El párrafo segundo del preámbulo de dicha ley concretaba lo siguiente: «Estos preceptos son insuficientes en ciertos casos para salvaguardar el bien jurídico de la solidaridad bumana, siempre de valía inestimable, y que en los tiempos actuales ha alcanzado relieve legislativo de alta importancia en las disposiciones protectoras de auxilio dictadas por el poder público» ${ }^{9}$. Precisamente esa expresa referencia en el preámbulo legal a la solidaridad bumana aglutinó las posturas doctrinales primarias que la señalaron como el bien jurídico directamente protegido por el tipo penal. Así, por ejemplo, Rodríguez Mourullo apunta que con este nuevo cuerpo legal surgió una auténtica corriente de humanización en nuestro Derecho penal ${ }^{10}$. Otros como Aráuz Ulloa señalan que el objetivo de esta ley de 1951 era ofrecer un verdadero marco jurídico para la salvaguarda de la solidaridad en las personas, como bien jurídico protegido ${ }^{11}$.

Del lado de esta primera postura doctrinal se posiciona, entre otros, Alamillo Canillas, a cuyo juicio en el delito de omisión del deber de socorro el bien jurídico protegido es «el mínimo de aquella virtud de la caridad hacia nuestros semejantes que, rebasando el concepto de la pura caridad,

tratada, acometida por un agresor injusto, ó constituida en otro conflicto que requiera los auxilios de la humanidad, será reprendido, y sufrirá arresto de uno á seis días, ó pagará una multa de diez reales de vellon á tres duros; observándose lo prevenido en el art. 128 del título preliminar respecto del que desempeñare esta obligación como allí se expresa».

${ }^{7}$ El CP de 19 de marzo de 1948 tipificó como falta de omisión del deber de socorro lo que anteriormente se tipificó como delito, y lo hace en su art. 472, apartados 11 y 12 . Tales preceptos rezaban lo siguiente: «Serán castigados con una multa de 5 á 15 duros [...] (11) los que encontrando perdido ó abandonado a un menor de siete años, no lo entregaren á su familia ó no lo recogieren ó depositaren en lugar seguro, dando cuenta á la Autoridad en los dos últimos casos [...] (12) los que no socorrieren ó auxiliaren á una persona que encontraren en despoblado herida, maltratada ó en peligro de perecer, cuando pudieren hacerlo sin detrimento propio».

${ }^{8}$ Ley de 17 de julio de 1951, por la que se castigan determinadas omisiones punibles (BOE, núm. 200, 19 de julio de 1951).

${ }^{9}$ Vid. párrafo segundo del preámbulo de la Ley de 17 de julio de 1951, por la que se castigan determinadas omisiones punibles (BOE, núm. 200, 19 de julio de 1951).

${ }_{10}$ G. Rodríguez Mourullo, La omisión de socorro en el Código Penal, Madrid, Tecnos, 1966, p. 127.

${ }_{11}$ M. Aráuz Ulloa, El delito de omisión del deber de socorro. Aspectos fundamentales, Valencia, Tirant lo Blanch, 2006, p. 37. 
ha venido a albergarse en el terreno de la justicia, asumiendo el nombre de solidaridad humana», con lo que este bien, inicialmente propio del campo de la moral cristiana, cobraría ahora relevancia social y constituiría un bien jurídico «exigible, imponible y, desde luego, protegible», postura que ha sido mantenida después por un amplio sector de la doctrina ${ }^{12}$.

Esta primera doctrina, que considera que el único bien tutelado por la norma es la solidaridad humana en modo directo, ha sido mayoritariamente abandonada en la actualidad, si bien todavía hoy perduran algunas afirmaciones tendentes a la defensa de esta tesis. Así, por ejemplo, Figueroa Ortega señala actualmente que «tanto el ordenamiento moral como el jurídico se sustentan en la solidaridad», siendo precisamente esa solidaridad el deber del que derivan hoy todas las normas jurídicas. Con base en estas ideas, «el Derecho lo que hace es plasmar jurídicamente la solidaridad requerida en el contexto» ${ }^{13}$.

Sin embargo, las doctrinas posteriores han venido rechazando la anterior posición, considerando que esta afirmación doctrinal, si bien encon-

${ }^{12}$ F. Alamillo Canillas, La solidaridad bumana en la ley penal, Madrid, Sección de Publicaciones del Ministerio de Justicia, 1962, p. 92. Además de Alamillo Canillas, otros autores se han posicionado en esta línea entendiendo que la norma penal trata de salvaguardar directamente el bien jurídico solidaridad humana. Así, E. Gimbernat Ordeig, Ensayos penales, Madrid, Tecnos, 1999, p. 204 [el artículo también puede consultase en C. M. RoMEO Casabona (ed.), Dogmática penal, política criminal y criminología en evolución, Tenerife, Centro de Estudios Criminológicos-Universidad de la Laguna, 1997, pp. 51-101]; J. M. NAVARRETE URIETA, «La omisión del deber de socorro. Exégesis y comentario del art. 489 bis del Código Penal», Revista de la Facultad de Derecho de la Universidad de Madrid, núm. 6 (1959), p. 423; J. A. SÁINZ CANTERO, «El delito de omisión del deber de socorro», Revista General de Legislación y Jurisprudencia, núm. 209 (julio-diciembre de 1960), p. 437; A. ToRío LóPEZ, «Aspectos de la omisión especial de socorro», en Anuario de Derecho Penal y Ciencias Penales, enero-agosto de 1967, pp. 588 y ss.; A. Quintano RIPOLlés, Tratado de la parte especial del Derecho penal, t. IV, Infracciones contra la comunidad social, Madrid, Revista de Derecho Privado, 1967, pp. 408-409; A. FERNÁNDEZ Albor, «Asistencia médica y omisión del deber de socorro», en Estudios Penales y Criminológicos, núm. VII, Santiago de Compostela, 1984, p. 158; J. A. Mora Alarcón, Suma de Derecho penal, parte general y especial, Madrid, Edisofer, 1996, p. 372; T. DEL CASO JimÉNEZ, «De la omisión del deber de socorro», en J. SÁNCHEZ Melgar (coord.), Código Penal, comentarios y jurisprudencia, t. I, 2. ${ }^{a}$ ed., Madrid, Sepin, Editorial Jurídica, 2006, p. 1140. Más actualmente, parece posicionarse en la misma dirección Robles Planas cuando, al referirse a la omisión de socorro delimitando ésta con la complicidad por actos omisivos, expresa que en la figura delictiva «sólo se infringe un deber general de solidaridad» (cursivas mías). Vid. R. Robles Planas, Garantes y cómplices. La intervención por omisión y en los delitos especiales, Barcelona, Atelier, Libros Jurídicos, 2007, p. 83.

13 Y. Figueroa Ortega, Delitos de infracción de deber, Madrid, Dykinson, 2008, p. 125. En el mismo sentido, aceptando que lo protegido por la norma es, sin más, la solidaridad, C. García Valdés, E. Mestre Delgado y C. Figueroa Navarro, Lecciones de Derecho Penal, parte especial (adaptadas a la docencia del Plan Bolonia), Madrid, Edisofer, Libros Jurídicos, 2011, p. 65. 
traba apoyo en el preámbulo de la Ley de 1951, no podía encontrar fundamento en el propio Código (pues precisamente los tipos penales de omisión estaban organizados en distintas rúbricas dentro del texto del CP) ${ }^{14}$. La concepción de la solidaridad humana como bien jurídico fue criticada por estos movimientos doctrinales posteriores por ser, en sí misma considerada, un auténtico valor ético-social que poseería, por tanto, una realidad que sería anterior a la realidad jurídica ${ }^{15}$ y que carecería de límites jurídicos, por lo que difícilmente se podría estimar como objeto de protección del tipo penal al no poder cumplir con las funciones que se le asignan a esta institución ${ }^{16}$.

\section{b) La seguridad de las personas como bien jurídico protegido}

Otra corriente doctrinal se ha inclinado por afirmar que el bien jurídico que se protege es el de la seguridad de las personas. En esta línea hay dos posiciones destacadas:

Por un lado, algunos autores señalan que lo protegido viene a ser la seguridad de modo directo. Así, Bustos Ramírez afirma que la consideración de estos deberes positivos de salvaguarda o socorro ajeno está en relación al art. 9.2 $\mathrm{CE}^{17}$, siendo protegido el bien jurídico seguridad como presupuesto de la libertad de la persona (esto es, estaríamos ante un interés instrumental en aras a tutelar la libertad) ${ }^{18}$.

Por otro lado, autores como Bajo Fernández y Díaz-Maroto Villarejo, manteniendo que la seguridad en abstracto no puede aportar nada, opinan que lo que protege este tipo penal es la seguridad de bienes personales

${ }^{14}$ En este sentido G. Rodríguez Mourullo, La omisión..., op. cit., p. 135; J. M. Rodríguez Devesa y A. Serrano Gómez, Derecho penal español, 18. a ed. revisada y puesta al día, Madrid, Dykinson, 1995, p. 120.

${ }^{15}$ G. Rodríguez Mourullo, La omisión..., op. cit., p. 138.

16 B. del Rosal Blasco, en M. Cobo Del Rosal (coord.), Derecho penal español. Parte especial, Madrid, Dykinson, 2004, p. 310; íD., «De la omisión del deber de socorro», en L. Morillas Cueva (coord.), Sistema de Derecho penal español, parte especial, Madrid, Dykinson, 2011, p. 286.

${ }^{17} \mathrm{El}$ apartado segundo del art. $9 \mathrm{CE}$ reza lo siguiente: «Corresponde a los poderes públicos promover las condiciones para que la libertad y la igualdad del individuo y de los grupos en que se integra sean reales y efectivas; remover los obstáculos que impidan o dificulten su plenitud y facilitar la participación de todos los ciudadanos en la vida política, económica, cultural y social».

${ }^{18}$ J. Bustos Ramírez, Manual de Derecho penal. Parte especial, 2. ${ }^{a}$ ed. aumentada, corregida y puesta al día, Barcelona, Ariel Derecho,1991, pp. 83-84. 
concretos, como la vida y la integridad personal ${ }^{19}$. Se trataría, según esta postura, de concretar un bien personal y concebir que lo que el tipo penal tutela es la salvaguarda o seguridad de los mismos.

\section{c) La solidaridad humana como bien jurídico protegido en forma medial}

La postura doctrinal que se ha venido considerando más extendida es la que contempla como bien jurídico protegido el valor de la solidaridad bumana cuando ello afecte o cause peligro a determinados bienes jurídicos individuales y concretos (como la vida e integridad de la persona, o incluso la libertad o libertad sexual). Según esta postura, con el tipo penal se vendría a proteger la solidaridad tan sólo de forma medial, en dirección a conseguir la salvaguarda de otros intereses (tesis que se mantiene también mayoritariamente en la jurisprudencia ordinaria e incluso por el Tribunal Constitucional ${ }^{20}$. La doctrina penal tradicional, como se expuso supra, se

19 M. Bajo Fernández y J. Díaz-Maroto Villarejo, Manual de Derecho penal, parte especial. Delitos contra la libertad y seguridad, libertad sexual, honor y estado civil, 2. ${ }^{a}$ ed., Madrid, Centro de Estudios Ramón Areces, 1991, pp. 71-72. En el mismo sentido M. L. Maqueda ABReu, Los delitos contra la libertad y la seguridad de las personas. Notas para un estudio doctrinal y jurisprudencial, Granada, Universidad de Granada, 1988, p. 93; M. C. Molina Blázquez, «El art. 195.3 del Código Penal de 1995: problemas de aplicación», Revista de Derecho Penal y Criminología, núm. 4 (1999), p. 571.

${ }^{20}$ Entre los autores que se sitúan al lado de esta postura, entre otros, G. RodRíGuEZ Mourullo, La omisión..., op. cit., p. 147; íd., en G. Rodríguez Mourullo (dir.) y J. BarReiro (coord.) et al., Comentarios al Código Penal, Madrid, Civitas, 1997, p. 554; F. MuÑOz Conde, Derecho penal, parte especial, 18. ${ }^{a}$ ed. revisada y puesta al día, Valencia, Tirant lo Blanch, 2010, p. 339; C. Blanco Lozano, La omisión del deber de socorro en el Derecho penal, Barcelona, Bosh, 2009, p. 91; R. Hernández Hernández, en C. Conde-Pumpido Ferreiro, Código Penal comentado, t. I, 2. a ed., Barcelona, Bosch, 2004, p. 607; B. DEL Rosal BlasCo, en M. Cobo del Rosal (coord.), Derecho penal español. Parte especial, Madrid, Dykinson, 2004, p. 310; íD., «De la omisión del deber de socorro», en L. Morillas Cueva (coord.), Sistema de Derecho penal español, parte especial, Madrid, Dykinson, 2011, p. 286; R. GarCía Albero, en G. Quintero Olivares (dir.) y F. Morales Prats (coord.), Comentarios a la parte especial del Derecho penal, 9. ${ }^{a}$ ed., Navarra, Thomson-Aranzadi, 2011, pp. 427-428; L. RoDRíguez Ramos, Compendio de Derecho penal (parte especial), 2. ${ }^{a}$ ed., Madrid, Trivium, 1987, pp. 168-169; M. Polaino Navarrete, en M. Cobo del Rosal (dir.) y C. Carmona Salgado, J. J. González Rus, L. Morillas Cueva et. al., Manual de Derecho penal, parte especial, t. I, Delitos contra las personas, la libertad sexual, el honor, el estado civil, la libertad y la seguridad, y los derechos individuales, Madrid, Revista de Derecho Privado-Editorial de Derecho Reunidas, 1993, p. 510; J. López Barja de Quiroga, en M. Cobo del Rosal (dir.), Comentarios al Código Penal, t. VII, Títulos IX, X, XI y XII del Libro II del vigente Código Penal espanol. Artículos 195 a 233, Madrid, Edersa, 1999, p. 24; E. Sola Reche, en J. L. Díez Ripollés y C. M. Romeo Casabona, Comentarios al Código Penal, parte especial II. Títulos VII-XII y 
había conformado hasta el momento con citar la solidaridad humana como bien directamente tutelado por el tipo, teniendo en cuenta sólo el preámbulo de la Ley de 1951, considerando como bien jurídico el interés o valor ético-social sobre el que incidía la protección penal y deteniendo el análisis en este punto; sin embargo, ese puro valor ético-social, según esta doctrina hoy dominante, padecería de una clara indeterminación en los límites jurídicos, por lo que por sí solo no podría ser considerado bien jurídico protegido $^{21}$. Si así fuese supondría extender la tutela penal más allá del propio ámbito de relevancia típica ${ }^{22}$. En palabras de Bajo Fernández y Díaz-Maroto Villarejo, «la carencia de límites y de contorno conceptual de la expresión solidaridad humana impide considerarla como bien jurí-

faltas correspondientes, Valencia, Tirant lo Blanch, 2004, p. 603; P. GÓMEz PAVÓN, «Comentario al art. 489 ter CP 1944/1973», en J. López Barja De Quiroga y L. Rodríguez Ramos (coords.), Código Penal comentado, Madrid, Akal, 1990, p. 929; G. Portilla Contreras, en G. Quintero Olivares y F. Morales Prats (coords.), El nuevo Derecho penal español. Estudios penales en memoria del profesor José Manuel Valle Muñiz, Navarra, Aranzadi, 2001, p. 1670; J. CARDOna TorRes, Derecho penal, parte especial. Adaptado a la reforma de la Ley Orgánica 5/2010, de 22 de junio, Barcelona, Bosch, 2010, p. 173; J. A. Choclán Montalvo, en A. Calderón Cerezo y J. A. Choclán Montalvo, Manual de Derecho penal II, parte especial. Adaptado al programa de las pruebas selectivas para ingreso en las carreras judicial y fiscal, Barcelona, Deusto, 2005, p. 122; F. J. Escrihuela Chumilla, Todo penal, Madrid, La Ley, 2011, p. 738. Por su parte, en la jurisprudencia del Tribunal Supremo puede ponerse como ejemplo la STS de 28 de enero de 2008, Sala 2. ${ }^{\text {a }}$ (Iustel § 275186), que expone en su FJ 3. ${ }^{\circ}$ que con la norma del art. $195.1 \mathrm{CP}$ «se sanciona genéricamente una conducta insolidaria, pero el legislador no le da una extensión indefinida, sino que la concreta a los supuestos de peligro manifiesto y grave para la vida o la integridad física». También recogen la idea de solidaridad la STS de 16 de mayo de 2002, Sala 2. ${ }^{a}$ (Iustel, § 330303); la STS de 22 de febrero de 1992, Sala 2. ${ }^{a}$ (Westlaw Aranzadi, RJ 1992/1306); la STS de 25 de junio de 1992, Sala 2. ${ }^{a}$ (Westlaw Aranzadi, RJ 1992/5884); la STS de 25 de octubre de 1993, Sala 2. ${ }^{a}$ (Westlaw Aranzadi, RJ 1993/7956); la STS de 5 de diciembre de 1989, Sala 2." (Westlaw Aranzadi, RJ 1989/9426); la STS de 27 de abril de 1987, Sala 2. ${ }^{\text {a }}$ (Westlaw Aranzadi, RJ 1987/2623); la STS de 13 de octubre de 1992, Sala 2. ${ }^{a}$ (Westlaw Aranzadi, RJ 1992/8315), o la STS de 26 de marzo de 1992, Sala 2." (Westlaw Aranzadi, RJ 1992/2480), entre otras. También el TC se pronuncia al respecto del bien jurídico protegido por el tipo penal de omisión del deber de socorro en la STC 180/2004, de 2 de noviembre, Sala 1. ${ }^{\text {a }}$ (Westlaw Aranzadi, RJ 2004/180). Analizando un supuesto de ne bis in idem al respecto de una sanción penal y una sanción administrativa, en su FJ $7 .^{\circ}$ apunta que el interés jurídicamente protegido por el delito de omisión del deber de socorro es «la mínima cooperación social exigible, la solidaridad humana, la vida o integridad física en peligro, la protección de los bienes primarios en desamparo, junto con el escaso riesgo en prestar el socorro; por tanto, la perspectiva dominante es la del interés de la persona desamparada y, secundariamente, el interés social en el recto comportamiento cooperativo entre los hombres».

${ }^{21}$ En este sentido, G. Rodríguez Mourullo, La omisión..., op. cit., pp. 138-139; J. A. Choclán Montalvo, en A. Calderón Cerezo y J. A. Choclán Montalvo, Manual de Derecho Penal II, parte especial..., op. cit., p. 122.

22 B. del Rosal Blasco, en M. Cobo del Rosal (coord.), Derecho penal español..., op. cit., p. 310.

Foro, Nueva época, vol. 15, núm. 2 (2012): 157-183 
dico protegido» ${ }^{23}$. Por eso se hizo necesario afirmar una ulterior precisión de bienes concretos que se protegían por medio de ese mandato de solidaridad, pues la invocación de la solidaridad en abstracto no decía mucho sobre la naturaleza del delito, ofreciendo un criterio sumamente vago.

En conclusión, como señala Muñoz Conde, en el delito de omisión del deber de socorro no existiría un «deber de socorro» genérico sancionable en sede penal, sino un deber de socorro respecto a determinados bienes personales (por ejemplo, la vida, la integridad física o la salud) que se encuentran en peligro en una situación concreta ${ }^{24}$. Precisamente por ello, esta postura doctrinal afirma que lo que el tipo viene a proteger son bienes individuales (que por lo general se identifican en la vida y la integridad física), abarcando el interés de la solidaridad tan sólo de una forma medial en relación con aquellos bienes individuales.

\section{d) La teoría de la protección directa de bienes jurídicos individuales}

Por último, un grupo de autores viene defendiendo en los últimos años que el interés protegido por este delito es en todo caso individual, y concluyen que este tipo penal protege directamente tales bienes individuales o personales (valores como la vida o la integridad e incluso otros como la libertad ambulatoria o sexual) ${ }^{25}$.

En este sentido, Molina Fernández considera que con la referencia a bienes jurídicos mediatos que se encuentran descendiendo del plano de la

${ }^{23}$ M. Bajo Fernández y J. Díaz-Maroto Villarejo, Manual de Derecho penal..., op. cit., pp. 71-72.

${ }^{24}$ F. MuÑoz Conde, Derecho penal, parte especial, op. cit., p. 339.

${ }^{25}$ En este sentido se posicionan, entre otros, F. Molina Fernández, en M. Bajo FerNÁNDEZ (dir.) et al., Compendio de Derecho penal (parte especial), vol. 2, Madrid, Centro de Estudios Ramón Areces, 1998, p. 143; J. C. Carbonell Mateu y J. L. González Cussac, en T. S. Vives Antón (coord.), Comentarios al Código Penal de 1995, Valencia, Tirant lo Blanch, 1996, p. 980; E. BACIGALUPO, «Notas a la propuesta de anteproyecto del Código Penal», Revista de la Facultad de Derecho de la Universidad Complutense, 1983, p. 68; C. LAMARCA PÉREZ (coord.) et al., Derecho penal, parte especial, 6. ${ }^{a}$ ed., Madrid, Colex, 2011, p. 191; A. SERRANo Gómez y A. Serrano Maíllo, Derecho penal, parte especial, 16. ${ }^{a}$ ed., Madrid, Dykinson, 2011, p. 266; F. M. Oliver EgeA, «Omisión del deber de socorro», en E. López López y E. Perdiguero Bautista, Enciclopedia penal, Madrid, La Ley, 2011, p. 998; M. Gómez Tomillo, El deber de socorro..., op. cit., p. 70; J. M. Rodríguez Devesa y A. Serrano Gómez, Derecho penal español, op. cit., pp. 120-121, M. ArÁUZ UlLÓA, El delito de omisión del deber de socorro..., op. cit., p. 180. También S. HuerTA Tocildo, Problemas fundamentales de los delitos de omisión, Madrid, Ministerio de Justicia, 1987, pp. 203-204, se sitúa en esta posición, crítica con el concepto «solidaridad» como bien jurídico, analizando el delito de omisión de los deberes de impedir y denunciar determinados delitos (actual art. $450 \mathrm{CP}$ ). 
seguridad o de la solidaridad se produjo un claro avance a la hora de concretar un bien jurídico sistemáticamente útil, con una clara voluntad de superar los inconvenientes de la excesiva abstracción de considerar la solidaridad como bien directamente protegido; pero estas opciones hoy hacen al sistema innecesariamente más complejo, oscureciendo además las relaciones entre los tipos penales ${ }^{26}$. Según este pensamiento, abandonar la teoría de la protección de bienes jurídicos colectivos a favor de intereses jurídicos individuales supone un claro avance en la concreción del verdadero bien que se pretende proteger por el tipo penal.

Además de recurrir al argumento ya analizado de la vaguedad y abstracción del concepto «solidaridad» que impediría concebirlo como bien jurídico, los argumentos empleados por este sector doctrinal para defender que los bienes jurídicos sean una serie de bienes personales concretos son de muy diverso tipo ${ }^{27}$.

Como advierte Aráuz Ulloa, esta interpretación, de carácter restrictivo, encuentra apoyo en el hecho de que el propio legislador, con la aprobación del CP de 1995, no incluyera el delito de omisión del deber de socorro entre los «delitos contra la seguridad colectiva» (lo que hace que se pueda rechazar la posibilidad de entender la seguridad como bien jurídico protegido en este tipo penal) y además no crease una rúbrica independiente en términos, por ejemplo, de «delitos contra la solidaridad humana» ${ }^{28}$.

Además, a juicio de Varona Gómez, se produciría una total imposibilidad a la hora de determinar los límites del tipo penal de omisión del deber de socorro si se acude a esa vaga referencia al concepto de solidaridad como valor protegido ${ }^{29}$.

Por su parte, Gómez Tomillo indica que una contemplación global del Código Penal permite constatar que el delito de omisión del deber de socorro se encuentra en una zona, dentro del Código, donde se protegen directamente bienes jurídicos individuales ${ }^{30}$. En la misma línea de pensamiento, Carbonell Mateu y González Cussac advierten que «el Estado,

${ }^{26}$ F. Molina Fernández, en M. Bajo Fernández (dir.), Compendio de Derecho penal..., op. cit., p. 143.

27 Aludiendo al carácter vago e impreciso y a la carga ética y moral del concepto de «solidaridad», vid. M. Gómez Tomillo, El deber de socorro..., op. cit., p. 39. Vid. también M. Gómez Tomillo, en M. Gómez Tomillo (dir.), Comentarios al Código Penal, Valladolid, Lex Nova, 2010, p. 776.

${ }_{28}$ M. ArÁuZ UlloA, El delito de omisión del deber de socorro..., op. cit., p. 180.

29 D. Varona Gómez, Derecho penal y solidaridad. Teoría y práctica del mandato penal de socorro, Madrid, Dykinson, 2005, p. 31.

30 M. Gómez Tomillo, El deber de socorro..., op. cit., p. 44. 
a través de la pena, no puede imponer a los ciudadanos ningún deber de solidaridad, porque entonces no se actúa por ese motivo, sino por sumisión a las normas» ${ }^{31}$.

Superada la concepción de la solidaridad humana como bien jurídico directamente protegido, la discusión doctrinal actualmente se centra en determinar si lo que se protege es la solidaridad en modo medial $\mathrm{o}$, por el contrario, se trata de una protección directa de bienes jurídicos individuales.

\section{B. El catálogo de bienes jurídicos concretos protegidos por la norma}

Una vez analizado lo anterior, el siguiente paso consiste en delimitar el catálogo de bienes concretos que la norma penal intenta proteger. En la actualidad existe un acuerdo doctrinal prácticamente unánime a la hora de señalar tanto a la vida como a la integridad física de las personas como intereses protegidos por el tipo penal, posición que es mantenida tanto por los que abogan por la idea de protección medial de la solidaridad como bien jurídico, como por parte de los que consideran que el tipo penal protege directamente bienes individuales ${ }^{32}$. La discusión, no obstante, se

31 J. C. Carbonell Mateu y J. L. González Cussac, en T. S. Vives Antón (coord.), Comentarios al Código Penal..., op. cit., p. 980. En el mismo sentido, C. LamarCa Pérez, Derecho penal, parte especial, op. cit., p. 191. El argumento es recogido también por F. J. Escrihuela Chumilla, Todo penal, op. cit., p. 738.

32 Así, por ejemplo, G. Rodríguez Mourullo, La omisión..., op. cit., p. 147; M. GÓmeZ Tomillo, El deber de socorro..., op. cit., p. 47; F. Molina Fernández, en M. Bajo FernánDEZ (dir.), Compendio de Derecho penal..., op. cit., pp. 144-145; F. Muñoz Conde, Derecho penal, parte especial, op. cit., p. 339; R. HernándeZ Hernández, en C. Conde-PumPido Ferreiro, Código penal comentado, op. cit., p. 607; B. Del Rosal Blasco, en M. Cobo DeL Rosal (coord.), Derecho penal español..., op. cit., p. 310; íd., en L. Morillas Cueva (coord.), De la omisión del deber de socorro, op. cit., pp. 286-287; M. BAJo Fernández y J. Díaz-Maroto Villarejo, Manual de Derecho penal..., op. cit., p. 72; R. García Albero, en G. Quintero Olivares (dir.), Comentarios a la parte especial..., op. cit., p. 428; E. Sola Reche, en J. L. Díez Ripollés y C. M. Romeo Casabona, Comentarios al Código Penal..., op. cit., p. 605; J. C. CaRbonell Mateu y J. L. González Cussac, en T. S. Vives Antón (coord.), Comentarios al Código Penal..., op. cit., p. 980; C. LAmarca Pérez, Derecho penal, parte especial, op. cit., p. 191; F. M. Oliver Egea, en E. López López y E. Perdiguero Bautista, Omisión del deber de socorro, op. cit., p. 998; M. L. MAQUEDA ABReu, Los delitos contra la libertad y la seguridad de las personas..., op. cit., p. 95; A. SERRAno Gómez y A. SERRAno Maíllo, Derecho penal, parte especial, op. cit., p. 266; P. Gomez Pavón, en J. López Barja y L. Rodríguez Ramos (coords.), Código Penal comentado, op. cit., p. 929; G. Portilla Contreras, en G. Quintero Olivares y F. Morales Prats (coords.), El nuevo Derecho penal español..., op. cit., p. 1669; M. Aráuz UlloA, El delito de omisión del deber de socorro..., op. cit., p. 186; J. M. RodríGuez DeveSa y A. Serrano Gómez, Derecho penal español, op. cit., pp. 120-121; C. Blanco Lozano, 
refiere más bien a la posibilidad de considerar que el precepto proteja también otros bienes: libertad ambulatoria, libertad sexual y dignidad.

Algunos autores han mantenido que bienes como la libertad ambulatoria o la libertad sexual no podrían ser en ningún caso protegidos en sede del art. $195 \mathrm{CP}$, pues la lesión a los mismos tendría siempre origen en una actuación delictiva de terceros ${ }^{33}$, por lo que dichos actos quedarían sancionados por vía del art. $450 \mathrm{CP}$, que contempla el tipo penal de omisión de impedir determinados delitos ${ }^{34}$.

Para otros, no obstante, además de la vida y la integridad o salud de las personas también podrían verse afectados bienes como la libertad o la libertad sexual, pues, a pesar de que ellos puedan encontrar protección en el ya citado delito del art. $450 \mathrm{CP}$ (pues se trata de hechos que comúnmente tienen su origen en una actividad delictiva de terceros), es posible que se den circunstancias en que el bien quede protegido por el tipo penal de omisión del deber de socorro, casos en que la situación de peligro o desamparo no tiene su origen en un hecho delictivo ${ }^{35}$.

La omisión del deber de socorro..., op. cit., pp. 90-93; B. Del Rosal Blasco, en L. MoriLlas Cueva (coord.), De la omisión del deber de socorro, op. cit., p. 287; J. CARDOna Torres, Derecho Penal, parte especial..., op. cit., p. 173, entre otros.

33 Así, por ejemplo, R. Hernández Hernández, en C. Conde-Pumpido Ferreiro, Código Penal comentado, op. cit., p. 607; M. Bajo Fernández y J. Díaz-Maroto Villarejo, Mamual de Derecho penal..., op. cit., p. 72; C. LamarCa Pérez, Derecho penal, parte especial, op. cit., p. 191; G. Portilla Contreras, en G. Quintero Olivares y F. Morales Prats, El nuevo Derecho penal español..., op. cit., p. 1670; M. L. MAQUEDA ABREU, Los delitos contra la libertad y la seguridad de las personas..., op. cit., p. 93; C. García Valdés, E. Mestre Delgado y C. Figueroa Navarro, Lecciones de Derecho Penal, parte especial..., op. cit., p. 66; F. J. Escrihuela Chumilla, Todo penal, op. cit., p. 738, entre otros. Por su parte, existen autores que admiten la posibilidad de sancionar en sede del art. 195 CP situaciones de desamparo o peligro para la libertad ambulatoria del sujeto, rechazando, no obstante, cualquier consideración del bien jurídico «libertad sexual». Es el caso, por ejemplo, de R. GARCÍA AlBERO, en G. Quintero Olivares (dir.), Comentarios a la parte especial..., op. cit., p. 428; F. MuÑoz Conde, Derecho penal, parte especial, op. cit., pp. 339-340; C. Blanco Lozano, La omisión del deber de socorro..., op. cit., p. 92.

${ }^{34} \mathrm{El}$ art. $450 \mathrm{CP}$ en su párrafo primero reza lo siguiente: «El que, pudiendo hacerlo con su intervención inmediata y sin riesgo propio o ajeno, no impidiere la comisión de un delito que afecte a las personas en su vida, integridad o salud, libertad o libertad sexual, será castigado con la pena de prisión de seis meses a dos años si el delito fuera contra la vida, y la de multa de seis a veinticuatro meses en los demás casos, salvo que al delito no impedido le correspondiera igual o menor pena, en cuyo caso se impondrá la pena inferior en grado a la de aquél».

${ }_{35}$ Así, por ejemplo, E. Sola Reche, en J. L. Díez Ripollés y C. M. Romeo Casabona, Comentarios al Código Penal..., op. cit., pp. 611-612; J. A. Choclán Montalvo, en A. Calderón Cerezo y J. A. Choclán Montalvo, Manual de Derecho penal II, parte especial..., op. cit., p. 124; A. Serrano Gómez y A. Serrano Maíllo, Derecho penal, parte especial, op. cit., p. 266; J. M. Rodríguez Devesa y A. Serrano Gómez, Derecho penal español, op. cit., p. 121; 
En esta última línea de pensamiento, a juicio de Choclán Montalvo, no habría razón alguna para excluir estos bienes jurídicos de la norma que sanciona la omisión de socorro, toda vez que si los mismos se protegen en el art. $450 \mathrm{CP}$ cuando la fuente de peligro es la actuación delictiva de un tercero, también ahora deben ampararse en el art. 195 CP cuando ese peligro emana de otras fuentes distintas ${ }^{36}$.

Así, en consideración al bien jurídico libertad, Molina Fernández pone el ejemplo de quien conociendo datos que demuestran la inocencia de un condenado a una pena privativa de libertad no acude a testificar, permitiendo esa injusta privación de libertad del sujeto ${ }^{37}$. Ejemplo más ilustrativo incluso resulta el que expone Blanco Lozano cuando habla de personas que quedan atrapadas en ascensores a las que no se les presta el socorro necesario ${ }^{38}$.

En lo referente a considerar la libertad sexual como bien jurídico protegido, Molina Fernández pone el ejemplo de una persona en peligro que logra transmitir a otra, por señas o por gritos, su situación, pero que, sin embargo, no puede explicar, en modo específico, que el riesgo procede de una inminente actuación delictiva de un tercero contra su libertad sexual (por ejemplo, una violación). Cuando el reclamado omite prestar auxilio podremos estar ante la comisión de un delito de omisión del deber de socorro del art. $195 \mathrm{CP}$ y no un delito de omisión del deber de impedir determinados delitos (art. $450 \mathrm{CP}$ ), pues, a juicio del autor, en aplicación del criterio de especialidad (en caso de concurso) se podría sancionar este comportamiento como delito del art. $195 \mathrm{CP}^{39}$.

M. GÓmez Tomillo, El deber de socorro..., op. cit., pp. 57-63; L. Rodríguez Ramos, Compendio de Derecho penal (parte especial), op. cit., p. 169; M. C. Molina BlázQuez, El art. 195.3 del Código Penal de 1995..., op. cit., p. 571; F. Molina Fernández, en M. Bajo Fernández (dir.), Compendio de Derecho penal..., op. cit., pp. 144-145.

36 J. A. Choclán Montalvo, en A. Calderón Cerezo y J. A. Choclán Montalvo, Manual de Derecho penal II, parte especial..., op. cit., p. 124.

37 F. Molina Fernández, en M. Bajo Fernández (dir.), Compendio de Derecho penal..., op. cit., p. 145 .

38 C. Blanco LozAno, La omisión del deber de socorro..., op. cit., p. 92.

39 F. Molina Fernández, en M. Bajo Fernández (dir.), Compendio de Derecho penal..., op. cit., pp. 145-146. Por su parte, el criterio de especialidad en materia de concurso de leyes se contempla en el apartado 1 del art. $8 \mathrm{CP}$, que reza lo siguiente: «Los hechos susceptibles de ser calificados con arreglo a dos o más preceptos de este Código, y no comprendidos en los arts. 73 a 77 , se castigarán observando las siguientes reglas: 1. El precepto especial se aplicará con preferencia al general. 2. El precepto subsidiario se aplicará sólo en defecto del principal, ya se declare expresamente dicha subsidiariedad, ya sea ésta tácitamente deducible. 3. El precepto penal más amplio o complejo absorberá a los que castiguen las infracciones consumidas en aquél. 4. En defecto de los criterios anteriores, el precepto penal más grave excluirá los que castiguen el hecho con pena menor». 
En definitiva, para estos autores pueden existir situaciones que, aunque sea extraño que acontezcan en la realidad, sean susceptibles de crear un supuesto de peligro o desamparo que no sea consecuencia de una acción delictiva y que recaigan dentro del ámbito del delito de omisión del deber de socorro.

Por último, otros autores como Gómez Tomillo señalan que también es posible admitir la dignidad como bien jurídico directamente protegido por el delito. Este autor apunta que, de lege data, el precepto penal puede admitir la tutela directa (no mediata) de la dignidad de la persona como bien jurídico protegido, si bien hace una propuesta de lege ferenda señalando que la solución a la duda de si la dignidad puede ser considerado bien jurídico protegido por este delito pasa por su tipificación en el marco de los denominados «delitos contra la integridad moral», en donde los supuestos de agresión directa a la dignidad del sujeto pasivo tienen un tratamiento propio y expreso ${ }^{40}$.

\section{Toma de postura}

En mi opinión, la opción de afirmar que el bien jurídico protegido debe ser directamente un bien (o conjunto de bienes) de carácter individual parece la más acertada. Y ello por varias razones.

En primer lugar, porque la solidaridad humana constituye, a mi juicio, un criterio sumamente vago e impreciso, carente de límites ciertos, que impediría limitar el ámbito de aplicación del tipo penal. La imprecisión derivada de este concepto dificulta al máximo la interpretación del tipo penal en su conjunto. Un Derecho penal moderno no puede pararse a proteger, sin más, la solidaridad interpersonal, sino que debe concretar al máximo posible los bienes objeto de tutela. Además, se trata de un concepto revestido de una innegable carga ética y moral, extraña al Derecho. La opción de señalar que los bienes jurídicamente tutelados son directamente bienes individuales permite, al contrario, sacar a la luz el verdadero núcleo del comportamiento típico.

A lo anterior podemos añadir que la concepción de la solidaridad como bien jurídico mediato protegido por el delito de omisión del deber

${ }^{40}$ M. Gómez Tomillo, El deber de socorro...., op. cit., pp. 56-57. En parecido sentido se posicionan E. Sola Reche, en J. L. Díez Ripollés y C. M. Romeo Casabona, Comentarios al Código Penal..., op. cit., pp. 611-612; J. M. Rodríguez Devesa y A. Serrano Gómez, Derecho penal español, op. cit., p. 121. 
de socorro hoy sólo puede ser relevante desde un punto de vista eminentemente dogmático, pero deja de ser trascendental en el momento de aplicar el tipo penal a la práctica, toda vez que los bienes mediatos no son, según doctrina mayoritaria, susceptibles de considerarse como tal intereses tutelados por el tipo penal (ni forman parte de éste), sino más bien finalidades perseguidas por el legislador. En este sentido, los pretendidos bienes mediales sólo estarían llamados a servir como mecanismo de interpretación de la norma penal, mas no podrían concebirse como bien jurídico protegido por el delito. Y el anterior planteamiento conduce de nuevo a rechazar la solidaridad como bien jurídico protegido en modo medial en este tipo penal: si estos bienes mediatos no pueden considerarse bienes directamente protegidos, sino sólo cumplir una función de auxilio interpretativo en algunos casos, por las razones manifestadas anteriormente estamos en disposición de rechazarlo como tal, toda vez que dicho término, al revestirse de esa innegable carga ética y moral que antes se apuntó, no serviría para facilitar el entendimiento de los elementos del tipo penal, sino más bien para dificultar su comprensión (por aquello de la vaguedad e imprecisión de la que se hablaba supra).

En segundo lugar, porque una interpretación sistemática del Código permite comprobar que el tipo del art. $195 \mathrm{CP}$ se encuentra en un marco donde se vienen a proteger bienes individuales o personales. En efecto, un mero vistazo a la estructura del texto legal permite apreciar que el delito de omisión del deber de socorro se encuentra recogido en un lugar concreto en que se contemplan delitos que en todo caso tutelan intereses de tipo personal o individual.

$\mathrm{Y}$ en tercer lugar, porque de imponerse en sede penal la obligación de actuar socorriendo como medio de protección de la «solidaridad» resultaría una consecuencia paradójica: el ciudadano no prestaría el auxilio por solidaridad, sino por sumisión al Derecho y por temor a la sanción penal. La solidaridad no es algo que pueda imponerse por medio del Derecho, es un sentimiento o comportamiento ligado, como se dijo, a la moral y a la ética personal de cada individuo. Si un Derecho (penal, en este caso) impusiere una obligación con objeto de salvaguardar un determinado comportamiento moral (en este caso, el deber de obrar solidariamente) se llegaría a una conclusión totalmente contraria: el ciudadano, uno de los destinatarios de las normas penales, se movería a cumplir con el mandato legal ya no por un sentimiento espontáneo de solidaridad (que es lo que se quiere, en teoría, proteger), sino porque una norma penal así lo obliga, y porque en caso de no cumplir con tal norma se le impondrá una consecuencia 
negativa, una pena. En efecto, la idea de que el Estado imponga un deber de actuación positiva basado en la solidaridad se vuelve contraria a lo que ese mismo Estado pretende con la promulgación de la norma: la solidaridad no puede ordenarse por la fuerza y bajo la amenaza de sanción penal, porque entonces se destruye en sí misma; se conseguirían así los efectos contrarios a los pretendidamente buscados por la norma: ya no se actuaría por solidaridad, sino por obligación.

En un segundo nivel de análisis debemos considerar, al fin, que entre esos bienes individuales pueden encontrarse tanto la vida como la integridad física, pero además también, en casos muy concretos (como ha podido comprobarse supra), la libertad ambulatoria (siempre que ésta no tenga origen en una actuación delictiva de terceros, pues se sancionarían en sede del art. $450 \mathrm{CP}$ ) y la libertad sexual (en supuestos en que el sujeto activo no puede percibir la concreta procedencia delictiva del peligro para la víctima, por criterios de especialidad). Si bien ambos bienes jurídicos difícilmente podrán ser objeto de ataque que no provenga de una actuación delictiva de terceras personas, hay casos muy concretos en que, al menos en un plano eminentemente teórico, sí pueden ser considerados como bienes jurídicos directamente protegidos por el art. $195 \mathrm{CP}^{41}$.

Por el contrario, no parecería correcto incluir en este catálogo otros bienes personales e individuales como el honor, pues la ubicación sistemática del art. 195 CP no lo aconseja. Pero es que, además de lo anterior, hay dos argumentos que pueden servir para desechar la concepción del honor como bien jurídico protegido. En primer lugar, porque el tipo penal exige que el sujeto activo se encuentre con una situación de «peligro manifiesto y grave», situación que resultaría cuanto menos tediosa de valorar a la hora de dilucidar qué se entiende por peligro grave y manifiesto en relación al honor de una persona. Y segundo, porque no debe olvidarse que estamos ante un tipo penal de omisión propia, y los mandatos de omisión siempre han de considerarse extraordinarios en Derecho penal (no se está sancionando al que con un comportamiento acti-

${ }^{41} \mathrm{Ha}$ de reconocerse que serán pocas y extrañas las situaciones en que los bienes jurídicos «libertad ambulatoria» o «libertad sexual» sufran un peligro que no provenga de una acción delictiva de terceros. No tanto en la libertad ambulatoria, pero sí al menos en lo que se refiere a la libertad sexual. No obstante, como se analizó supra, es posible que en ocasiones sí acontezca una lesión a la libertad sexual en que, por criterios de especialidad, se sancione en sede de omisión del deber de socorro (incluso puede imaginarse el supuesto de que sea un animal quien esté atentando contra la libertad sexual de un tercero; si quien apercibe tal situación no presta el socorro que debe prestar, pudiera ser imputado éste por un delito de omisión del deber de socorro, siempre que concurran el resto de elementos del tipo penal). 
vo causa un peligro o lesión a un tercero, sino a quien no cumple con un deber impuesto por la norma penal). No parecería lógico extender el cumplimiento del deber de socorro a los ciudadanos respecto de un hipotético ataque al honor de un tercero (pues, además, teniendo en cuenta que uno de los requisitos estructurales del tipo de omisión es la posibilidad de actuar cumpliendo el deber, es altamente difícil pedir una actuación de auxilio eficaz a quien contempla un ataque contra el honor de una persona; ¿cómo se socorre al agredido?).

Por todo lo expuesto creemos que, en definitiva, el tipo penal de omisión del deber de socorro del art. $195 \mathrm{CP}$ viene a proteger bienes individuales de forma directa, y que entre tales bienes, dependiendo de los casos, se encuentran la vida, la integridad física y la salud de la persona, además de la libertad ambulatoria y la libertad sexual ${ }^{42}$.

\section{PROPORCIONALIDAD Y SANCIÓN PENAL. PROPUESTA DE LEGE FERENDA}

Se ha llegado a la conclusión de que el delito de omisión del deber de socorro protege bienes muy diversos; coexisten, por tanto, distintos intereses objeto de tutela en un mismo tipo penal, lo que ha de concretarse dependiendo del supuesto fáctico que acontezca en la realidad. Y sin embargo, pese a que el tipo penal protege intereses de tipo muy diverso, la pena que se contempla a modo de consecuencia jurídico-penal en los arts. 195.1 y 195.2 CP es la misma: multa de tres a doce meses. Debemos preguntarnos entonces si este hecho resulta o no coherente con la justicia material que debe buscar todo Derecho (y, más concretamente en este supuesto, el penal) y con la igualdad y proporcionalidad que deben inspirar al mismo. Adelantamos ya que, en nuestra opinión, el hecho de que un mismo tipo penal, que protege bienes tan diversos, contemple idéntica pena ante múltiples y distintas posibilidades de ataque no puede casar en modo alguno con tales principios, desaconsejándose, por tanto, esta consecuencia jurídica.

Podemos partir aquí de dos supuestos imaginarios:

${ }^{42}$ No pueden concebirse otros bienes jurídicos diferentes (por ejemplo, el patrimonio) toda vez que el tipo penal del art. 195.1 CP habla de persona desamparada y en peligro manifiesto y grave. Por tanto, deben concebirse como objeto de protección tan sólo bienes personales. 
a) El sujeto $X$ sufre un ataque al corazón que le hace caer en la vía pública ante un par de espectadores que lo presencian impasibles y que, sin más, abandonan a la víctima sin prestar el socorro debido, lo que acarrea, además, la muerte de $\mathrm{X}$ como fatal desenlace.

b) El sujeto $\mathrm{Y}$, tras subir al ascensor que le lleva a casa, queda encerrado en el mismo por un corte de suministro eléctrico inesperado. Un par de vecinos que suben por la escalera oyen sus gritos de auxilio y, aun conociendo de su estado, abandonan el lugar sin prestar el socorro debido ni demandarlo a terceros. El sujeto Y, tras cuatro horas encerrado, consigue salir del ascensor con ayuda de terceros.

Mientras en el ejemplo (a) el sujeto X sufre un peligro en su bien jurídico «vida» e incluso se llega al resultado de muerte, en el ejemplo (b) el sujeto Y logra salir ileso de su encierro tras unas horas privado de su «libertad ambulatoria». Sin embargo, tanto a los omitentes del caso (a) como a los omitentes del caso (b) se les sancionará con idéntica pena: multa de tres a doce meses. No sirve aquí el posible contraargumento de que estamos ante un delito de omisión pura o propia, algo en lo que estoy de acuerdo, como lo está la práctica totalidad de la doctrina penal ${ }^{43}$. En la discusión

${ }^{43}$ En este sentido se postulan, entre otros, F. Alamillo Canillas, La solidaridad humana en la ley penal, op. cit., p. 64; F. Molina Fernández, en M. Bajo Fernández (dir.), Compendio de Derecho penal..., op. cit., p. 153; F. MuÑoz CONDE, Derecho penal, parte especial, op. cit., p. 341; R. Hernández Hernández, en C. Conde-Pumpido Ferreiro, Código Penal comentado, op. cit., pp. 607-608; M. Bajo Fernández y J. Díaz-Maroto Villarejo, Manual de Derecho penal..., op. cit., p. 73; R. García Albero, en G. Quintero Olivares (dir.), Comentarios a la parte especial..., op. cit., p. 428; P. GÓmez PAvÓN, en J. LóPez BARJa y L. RodríGuez Ramos (coords.), Código Penal comentado, op. cit., p. 930; E. Sola Reche, en J. L. Díez Ripollés y C. M. Romeo Casabona, Comentarios al Código Penal..., op. cit., p. 617; C. Lamarca Pérez, Derecho penal, parte especial, op. cit., p. 192; J. M. NAVARRETe URIETA, La omisión del deber de socorro..., op. cit., p. 422; L. RoDRíguez Ramos, Compendio de Derecho penal (parte especial), op. cit., p. 170; G. Portilla Contreras, en G. Quintero Olivares y F. Morales Prats, El nuevo Derecho penal español..., op. cit., p. 1670; B. DEL Rosal Blasco, en L. Morillas Cueva (coord.), De la omisión del deber de socorro, op. cit., p. 287; C. VázQuez IRUZuBIETA, Nuevo Código Penal comentado, Madrid, Edersa-Editorial de Derecho Reunidas, 1996, pp. 290-291; T. DEL CASO Jiménez, en J. SÁnChEz Melgar (coord.), De la omisión del deber de socorro, op. cit., p. 1138; J. A. MORA AlARCón, Suma de Derecho penal, parte general y especial, op. cit., p. 373; J. CARDONA TORRES, Derecho penal, parte especial..., op. cit., pp. 173-174; J. A. Choclán Montalvo, en A. Calderón Cerezo y J. A. Choclán Montalvo, Manual de Derecho penal II, parte especial..., op. cit., p. 122; G. Quintero Olivares, Parte general del Derecho penal (con la colaboración de Fermín Morales Prats), 4. ${ }^{a}$ ed. revisada, ampliada y puesta al día, Navarra, Aranzadi-Thomson Reuters, 2010, p. 390; R. EsCOBAR JimÉNEZ, en P. CRESpo Barquero, R. Escobar Jiménez, C. Madrigal Martínez-Mereda, M. Marchena Gómez et al., Código Penal de 1995. Comentarios y jurisprudencia, Granada, Comares, 1998, p. 1090; C. García Valdés, E. Mestre Delgado y C. Figueroa Navarro, Lecciones de Derecho penal, parte especial..., op. cit., p. 65; C. BlanCO LozANO, La omisión del deber de socorro..., op. cit., 
que aquí traemos a colación no se trata de modular la pena en atención al resultado final que se deriva de la omisión (pues entonces estaríamos calificando al art. 195 CP como delito de resultado), sino de modular la pena en atención a la mera omisión que se produce ante distintos peligros, peligros que pueden ser más graves (por ejemplo, al afectar a la vida) o pueden ser más leves (por ejemplo, afectando a la libertad ambulatoria), teniendo en cuenta los bienes jurídicos en riesgo.

Algunos podrán opinar que la solución pasa porque deba ser el juez quien después gradúe y concrete la sanción penal según los casos, sancionando con menor multa a los omitentes del caso b) (como mínimo, tres meses) que a los omitentes del caso $a$ ), a quien se les deberá imponer una multa mayor (como máximo, doce meses). Se trata sin duda de una solución práctica, pero, a mi juicio, insuficiente: la solución debe pasar más bien por plasmar la justicia material en el texto de la ley, siendo el texto legal el que responda correctamente a los cánones de igualdad y de proporcionalidad que inspiran el sistema penal actual. Y es obvio que, ante los ejemplos anteriores, queda patente, a mi juicio, que no es así. Se rompe el principio de igualdad: se tratan por igual supuestos que son totalmente diferentes. Surge la misma consecuencia jurídica ante casos que lesionan bienes muy distintos. O en resumen, compartiendo las palabras de Gómez Tomillo, «la

p. 79; J. M. Rodríguez Devesa y A. Serrano Gómez, Derecho penal español, op. cit., p. 122; A. Serrano Gómez y A. Serrano Maíllo, Derecho penal, parte especial, op. cit., p. 268; J. Cerezo Mir, Derecho penal, parte general. Lecciones, 2. ${ }^{a}$ ed., Madrid, Universidad Nacional de Educación a Distancia UNED, 2000, p. 222; íD., Curso de Derecho penal español, parte general, vol. III, Teoría Jurídica del Delito (2), Madrid, Tecnos, 2004, p. 255; F. M. OLIVER Egea, en E. López López y E. Perdiguero Bautista, Omisión del deber de socorro, op. cit., p. 999; F. J. Escrihuela Chumilla, Todo penal, op. cit., p. 738; P. Martín García, «El delito de omisión del deber de socorro», Boletín del Ministerio de Justicia, núm. 1087, 25 de febrero de 1977, p. 11; C. SuÁrez-Mira Rodríguez (coord.) y A. Judiel Prieto y J. R. Piñol RodríGuEz, Manual de Derecho penal, t. II, Parte especial, 6. ${ }^{a}$ ed., Pamplona, Civitas-Thomsom Reuters, 2011, p. 193; J. M. LuZÓn Cuesta, Compendio de Derecho penal, parte especial. Adaptado al programa de la oposición a ingreso en las carreras judicial y fiscal, 18. ${ }^{a}$ ed. (13. ${ }^{a}$ ed. conforme al CP de 1995), Madrid, Dykinson, 2011, p. 108; A. CALderón Cerezo y J. Choclán Montalvo (coords.), Código Penal comentado, concordado, jurisprudencia y doctrina. Legislación penal especial y normas complementarias, Bilbao, Deusto Jurídico, 2005, p. 445; J. CuELlo ConTREras y B. Mapelli Caffarena, Curso de Derecho penal. Parte general, Madrid, Tecnos, 2011, pp. 180-181; I. Berdugo Gómez de la Torre, L. Arroyo Zapatero, J. C. Ferré Olivé et al., Curso de Derecho penal, parte general, 2. ${ }^{a}$ ed. adaptada a la reforma de 2010 del Código Penal, Barcelona, Experiencia, 2010, p. 240; E. J. Pérez Alonso, en J. M. Zugaldía Espinar (dir.) y M. R. Moreno-Torres Herrera et al. (coords.), Fundamentos de Derecho penal (parte general), Valencia, Tirant lo Blanch, 2010, p. 475; J. Cuello Contreras, El Derecho penal espanol, parte general, vol. II, Teoría del Delito (2), Madrid, Dykinson, 2009, p. 486; G. RodríGUEZ Mourullo, La omisión..., op. cit., p. 158; íD., en G. Rodríguez Mourullo (dir.) y J. BarReiro et al. (coords.), Comentarios al Código Penal, op. cit., p. 554. 
sanción en la regulación actual es idéntica en todos los casos y tan sólo cabe el recurso a la matización judicial de la pena para obtener una respuesta diferenciada. Procede, pues, que desde la propia ley se distinga punitivamente lo que desde un punto de vista teórico no es igual» ${ }^{44}$.

Para fundamentar un poco más mi opinión, podemos acudir a contrastar el art. $195 \mathrm{CP}$ con otros tipos penales omisivos que guardan ciertas similitudes con el delito de omisión del deber de socorro: el art. $412.3 \mathrm{CP}$ (delito de denegación de auxilio por funcionario público) y el art. 450.1 CP (delito de omisión del deber de impedir determinados delitos).

En primer lugar, el art. 412.3 CP reza lo siguiente: «La autoridad o funcionario público que, requerido por un particular a prestar algún auxilio a que venga obligado por razón de su cargo para evitar un delito contra la vida de las personas, se abstuviera de prestarlo, será castigado con la pena de multa de dieciocho a veinticuatro meses e inhabilitación especial para empleo o cargo público por tiempo de tres a seis años. Si se tratase de un delito contra la integridad, libertad sexual, salud o libertad de las personas, será castigado con la pena de multa de doce a dieciocho meses y suspensión de empleo o cargo público de uno a tres años. En el caso de que tal requerimiento lo fuera para evitar cualquier otro delito u otro mal, se castigará con la pena de multa de tres a doce meses y suspensión de empleo o cargo público por tiempo de seis meses a dos años». Se trata de un tipo penal que contempla diferentes consecuencias jurídicas ante distintos ataques a variados bienes jurídicos. Así, cuando el peligro se cierne sobre el bien «vida», el legislador ha previsto una pena de multa de dieciocho a veinticuatro meses, además de la inhabilitación especial de tres a seis años, para quien omite el auxilio. Por el contrario, cuando el peligro recae sobre el resto de bienes (integridad, libertad sexual o ambulatoria, salud), el legislador ha previsto una pena menor, en cumplimiento de los principios de igualdad y de proporcionalidad, que supone al omitente una multa de entre doce y dieciocho meses, además de la suspensión de empleo de uno a tres años.

En segundo lugar, el art. 450.1 CP reza así: «El que, pudiendo hacerlo con su intervención inmediata y sin riesgo propio o ajeno, no impidiere la comisión de un delito que afecte a las personas en su vida, integridad o salud, libertad o libertad sexual, será castigado con la pena de prisión de seis meses a dos años si el delito fuera contra la vida, y la de multa de seis a veinticuatro meses en los demás casos, salvo que al delito no impedido le correspondiera igual o menor pena, en cuyo caso se impondrá la pena infe-

${ }^{44}$ M. Gómez Tomillo, El deber de socorro..., op. cit., pp. 154-157. 
rior en grado a la de aquél». Ocurre en este tipo penal algo semejante al anterior art. $412.3 \mathrm{CP}$ : el legislador prevé una pena mayor cuando el peligro lo es contra la vida y una pena más reducida si el peligro surge contra el resto de bienes objeto de tutela.

Salvando las diferencias entre las distintas figuras estudiadas, que obviamente existen, nos encontramos ante delitos omisivos que sancionan la inactividad del sujeto obligado por una norma penal preceptiva a prestar socorro o ayuda en determinados casos (como ya se ha dicho, con las diferencias existentes; en el primer ejemplo se trata de un sujeto activo funcionario, esto es, un delito especial; en el segundo ejemplo se trata de una fuente de peligro delictiva). En ambos casos, la sanción se ha querido modular y graduar proporcionalmente por el legislador en atención a los distintos ataques a bienes jurídicos en peligro.

Si se llega a la conclusión, como yo hago, de que el tipo penal de omisión del deber de socorro protege en la práctica bienes individuales como la vida, la integridad, la libertad ambulatoria o la libertad sexual (por las distintas razones esgrimidas supra), y si el tipo penal contempla, como lo hace, una única consecuencia jurídica, la misma pena ante los múltiples y diversos ataques que pueden producirse, entonces llegamos a la conclusión de que algo falla. Falla el respeto al principio de igualdad y falla la proporcionalidad. Y todo ello nos obliga a postular la necesidad de un cambio legislativo. Cambio que debería producirse en un doble sentido: primero contemplando expresamente en el tipo los distintos bienes objeto de tutela, y segundo, y de la mano, las distintas penas escalonadas según diferentes ataques ${ }^{45}$. Compartimos las palabras exactas de Gómez Tomillo, quien asevera que «no puede estimarse idéntica la inactividad cuando lo que se halle en peligro sea la vida que cuando lo que esté en situación de riesgo sea un bien jurídico central, pero de menor rango, como lo es la salud o la libertad» ${ }^{46}$.

Como ya apuntase Beccaria, «más fuertes deben ser los motivos que retraigan a los hombres de los delitos a medida que son contrarios al bien público [...] Debe por esto haber una proporción entre los delitos y las penas» ${ }^{47}$. Este principio de proporcionalidad, que tantos ríos de tinta ha hecho correr posteriormente, es el epicentro inspirador del análisis que he dejado planteado. Merece la pena traer a colación, a modo de síntesis, la definición que de

${ }^{45}$ En este sentido C. Blanco Lozano, La omisión del deber de socorro..., op. cit., pp. 157-158-

46 M. Gómez Tomillo, El deber de socorro..., op. cit., p. 154.

47 C. Beccaria, De los delitos y de las penas, con estudio preliminar de J. Jiménez VillaREJO y traducción de J. A. de las Casas, Madrid, Tecnos, 2008, pp. 24-27. 
principio de proporcionalidad ha realizado el Grupo de Estudios de Política Criminal, entendiendo que éste «exige una correlación entre la gravedad de la infracción penal y la consecuencia jurídica prevista para la misma, tanto en la calidad como en la cantidad de tal consecuencia. Es por ello necesario contar con un amplio y diversificado elenco de penas que se acomode a la distinta naturaleza de las infracciones penales y a la distinta necesidad de intervención punitiva» ${ }^{48}$. Es obvio, a mi juicio, que para respetar tal postulado será necesario acudir a una fórmula legal que module las distintas penas en respuesta a diferentes ataques y bienes jurídicos en peligro. En suma, si se considera, como yo hago, que el bien jurídico es un importante criterio rector del delito, no puede pasarse por alto el hecho de que si el tipo penal protege bienes diversos, estos bienes tienen que operar como criterio de medición a la hora de establecer la pena. Y por ello el tipo penal del art. $195 \mathrm{CP}$ debiera prever diferentes penas ante distintos ataques.

\section{CONCLUSIONES}

El delito de omisión del deber de socorro del art. 195 CP es un tipo penal que viene a proteger de manera directa una serie de bienes jurídicos individuales o personales, sin poderse concebir a la «solidaridad» ni a la «seguridad» en abstracto como intereses tutelados por el tipo. Así, el Derecho penal protege directamente por medio de esta figura bienes como la vida y la integridad física, pero también en determinadas ocasiones otros intereses como la libertad ambulatoria o la libertad sexual, que si bien sólo podrán dar lugar al delito de omisión de socorro en muy contadas ocasiones, son supuestos susceptibles de acontecer en la realidad (siempre que tales bienes no queden ya protegidos de manera efectiva por otros tipos penales, como, por ejemplo, el delito del art. 450 CP que sanciona al que omite su actuación ante un peligro derivado de una actuación delictiva de terceros).

Pese a que el delito del art. $195 \mathrm{CP}$ protege bienes individuales muy diversos, encontramos que el precepto, en sus dos primeros apartados, contempla una única e idéntica pena para sancionar las omisiones que pueden generarse ante distintos bienes jurídicos concretos que se encuentren en peligro en cada caso. Ello resulta inconcebible desde un punto de vista sistemático (en comparación con otros delitos omisivos del Código Penal)

$48 \mathrm{Vid}$. «Una propuesta alternativa al sistema de penas y su ejecución, y a las medidas cautelares personales» (documentos), Grupo de Estudios de Política Criminal, 2005, p. 25. 
y desde el punto de vista de la proporcionalidad penal y la justicia material. Sería aconsejable que de lege ferenda, el tipo penal graduase las penas, modulándolas en función a los diferentes bienes jurídicos en peligro en cada caso concreto.

\section{BIBLIOGRAFÍA}

Alamillo Canillas, F., La solidaridad bumana en la ley penal, Madrid, Sección de Publicaciones del Ministerio de Justicia, 1962.

Aráuz Ulloa, M., El delito de omisión del deber de socorro. Aspectos fundamentales, Valencia, Tirant lo Blanch, 2006.

Bacigalupo, E., «Notas a la propuesta de anteproyecto del Código Penal», Revista de la Facultad de Derecho de la Universidad Complutense, 1983.

Bajo Fernández, M., y Díaz-Maroto Villarejo, J., Manual de Derecho penal, parte especial. Delitos contra la libertad y seguridad, libertad sexual, honor y estado civil, 2. ${ }^{a}$ ed., Madrid, Centro de Estudios Ramón Areces, 1991.

BeCCARIA, C., De los delitos y de las penas, con estudio preliminar de J. JimÉnez Villarejo y traducción de J. A. de las Casas, Madrid, Tecnos, 2008.

Berdugo Gómez de la Torre, I.; Arroyo Zapatero, L.; Ferré Olivé, J. C., et. al., Curso de Derecho penal, parte general, 2. ${ }^{a}$ ed. adaptada a la reforma de 2010 del Código Penal, Barcelona, Experiencia, 2010.

Blanco Lozano, C., La omisión del deber de socorro en el Derecho penal, Barcelona, Bosch, 2009.

Bustos Ramírez, J., Manual de Derecho penal. Parte especial, 2. ${ }^{a}$ ed. aumentada, corregida y puesta al día, Barcelona, Ariel Derecho, 1991.

Bustos Ramírez, J. J., y HormazÁbal Malarée, H., Nuevo sistema de Derecho penal, Madrid, Trotta, 2004.

Bustos Rubio, M., La tipicidad objetiva en el delito de omisión del deber de socorro personal, Madrid, Servicio de Publicaciones de la Facultad de Derecho UCM, 2013.

Calderón Cerezo, A., y Choclán Montalvo, J. (coords.), Código Penal comentado, concordado, jurisprudencia y doctrina. Legislación penal especial y normas complementarias, Bilbao, Deusto Jurídico, 2005.

Carbonell Mateu, J. C., y González Cussac, J. L., en Vives Antón, T. S. (coord.), Comentarios al Código Penal de 1995, Valencia, Tirant lo Blanch, 1996.

Cardona Torres, J., Derecho penal, parte especial. Adaptado a la reforma de la Ley orgánica 5/2010, de 22 de junio, Barcelona, Bosch, 2010.

Cerezo Mir, J., Curso de Derecho penal español, parte general, vol. 3, Teoría Jurídica del Delito (2), Madrid, Tecnos, 2004.

- Derecho penal, parte general: lecciones, 2. ${ }^{\text {a }}$ ed., Madrid, Universidad Nacional de Educación a Distancia UNED, 2000. 
Choclán Montalvo, J. A., en Calderón Cerezo, A., y Choclán Montalvo, J. A., Manual de Derecho Penal II, parte especial. Adaptado al programa de las pruebas selectivas para ingreso en las carreras judicial y fiscal, Barcelona, Deusto, 2005.

Cuello Contreras, J., El Derecho penal español, parte general, vol. 2, Teoría del Delito (2), Madrid, Dykinson, 2009.

Cuello Contreras, J., y Mapelli Caffarena, B., Curso de Derecho penal. Parte general, Madrid, Tecnos, 2011.

Del Caso Jiménez, T., «De la omisión del deber de socorro», en J. Sánchez MelGAR (coord.), Código Penal, comentarios y jurisprudencia, t. I, 2. ' ed., Madrid, Sepin, Editorial Jurídica, 2006.

Del Rosal Blasco, B., en Cobo del Rosal, M. (coord.), Derecho penal español. Parte especial, Madrid, Dykinson, 2004.

- «De la omisión del deber de socorro», en L. Morillas Cueva (coord.), Sistema de Derecho penal español, parte especial, Madrid, Dykinson, 2011.

Escobar Jiménez, R., en Crespo Barquero, P.; Escobar Jiménez, R.; Madrigal Martínez-Mereda, C.; Marchena Gómez, M., et. al., Código Penal de 1995. Comentarios y jurisprudencia, Granada, Comares, 1998.

Escrihuela Chumilla, F. J., Todo penal, Madrid, La Ley, 2011.

Fernández Albor, A., «Asistencia médica y omisión del deber de socorro», en Estudios Penales y Criminológicos, núm. VII, Santiago de Compostela, 1984.

Figueroa Ortega, Y., Delitos de infracción de deber, Madrid, Dykinson, 2008.

García Albero, R., en Quintero Olivares, G. (dir.), y Morales Prats, F. (coord.), Comentarios a la parte especial del Derecho penal, 9. ${ }^{a}$ ed., Navarra, Thomson Aranzadi, 2011.

García Valdés, C.; Mestre Delgado, E., y Figueroa Navarro, C., Lecciones de Derecho Penal, parte especial (adaptadas a la docencia del Plan Bolonia), Madrid, Edisofer, Libros Jurídicos, 2011.

Gimbernat Ordeig, E., Ensayos penales, Madrid, Tecnos, 1999.

Gimbernat Ordeig, E., en Romeo Casabona, C. M. (ed.), Dogmática penal, politica criminal y criminología en evolución, Tenerife, Centro de Estudios Criminológicos-Universidad de la Laguna, 1997.

Gómez Pavón, P., «Comentario al art. 489 ter CP 1944/1973», en J. LóPez Barja de Quiroga y L. Rodríguez Ramos (coords.), Código penal comentado, Madrid, Akal, 1990.

Gómez Tomillo, M., El deber de socorro (art. 195.1 del Código Penal), Valencia, Tirant lo Blanch, 2003.

- (dir.), Comentarios al Código Penal, Valladolid, Lex Nova, 2010.

Hernández Hernández, R., en Conde-Pumpido Ferreiro, C., Código penal comentado, t. I, 2. ${ }^{a}$ ed., Barcelona, Bosch, 2004.

Huerta Tocildo, S., Problemas fundamentales de los delitos de omisión, Madrid, Ministerio de Justicia, 1987.

Lamarca Pérez, C. (coord.), et. al., Derecho penal, parte especial, 6. ${ }^{a}$ ed., Madrid, Colex, 2011. 
Landecho Velasco, C. M., y Molina Blázquez, C., Derecho penal español. Parte

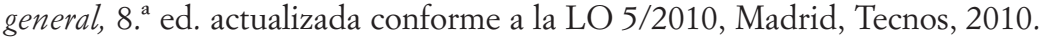

López Barja de Quiroga, J., en Cobo del Rosal, M. (dir.), Comentarios al Código Penal, t. VII, Títulos IX, X, XI y XII del Libro II del vigente Código Penal español. Arts. 195 a 233, Madrid, Edersa, 1999.

Luzón Cuesta, J. M., Compendio de Derecho penal, parte especial. Adaptado al programa de la oposición a ingreso en las carreras judicial y fiscal, 18. ${ }^{\mathrm{a}}$ ed. (13. ${ }^{\mathrm{a}} \mathrm{ed}$. conforme al CP de 1995), Madrid, Dykinson, 2011.

Maqueda Abreu, M. L., Los delitos contra la libertad y la seguridad de las personas. Notas para un estudio doctrinal y jurisprudencial, Granada, Universidad de Granada, 1988.

Martín García, P., «El delito de omisión del deber de socorro», Boletín del Ministerio de Justicia, núm. 1087, 25 de febrero de 1977.

Molina Blázquez, M. C., «El art. 195.3 del Código Penal de 1995: problemas de aplicación», Revista de Derecho Penal y Criminología, núm. 4 (1999).

Molina Fernández, F., en Bajo Fernández, M. (dir.), et al., Compendio de Derecho penal (parte especial), vol. 2, Madrid, Centro de Estudios Ramón Areces, 1998.

Mora Alarcón, J. A., Suma de Derecho penal, parte general y especial, Madrid, Edisofer, 1996.

Muñoz Conde, F., Teoría general del delito, 4. ${ }^{a}$ ed., Valencia, Tirant lo Blanch, 2007.

Muñoz Conde, F., y García ArÁn, M., Derecho penal, parte general, 8. a ed. revisada y puesta al día, Valencia, Tirant lo Blanch, 2010.

Navarrete Urieta, J. M., «La omisión del deber de socorro. Exégesis y comentario del art. 489 bis del Código Penal», Revista de la Facultad de Derecho de la Universidad de Madrid, núm. 6 (1959).

Polaino Navarrete, M., en Cobo del Rosal, M. (dir.); Carmona Salgado, C.; GonzÁlez Rus, J. J.; Morillas Cueva, L., et al., Manual de Derecho penal, parte especial, t. I, Delitos contra las personas; la libertad sexual; el honor; el estado civil; la libertad y la seguridad, y los derechos individuales, Madrid, Revista de Derecho Privado-Editorial de Derecho Reunidas, 1993.

Quintano Ripollés, A., Tratado de la parte especial del Derecho penal, t. IV, Infracciones contra la comunidad social, Madrid, Revista de Derecho Privado, 1967.

Oliver Egea, F. M., «Omisión del deber de socorro», en E. López López y E. PerDiguero Bautista, Enciclopedia penal, Madrid, La Ley, 2011.

Planas, R., Garantes y cómplices. La intervención por omisión y en los delitos especiales, Barcelona, Atelier, Libros Jurídicos, 2007.

Portilla Contreras, G., en Quintero Olivares, G., y Morales Prats, F. (coords.), El nuevo Derecho penal español. Estudios penales en memoria del profesor José Manuel Valle Muñiz, Navarra, Aranzadi, 2001.

Quintero Olivares, G., Parte general del Derecho penal (con la colaboración de Fermín Morales Prats), 4. ${ }^{a}$ ed. revisada, ampliada y puesta al día, Navarra, Aranzadi, 2010. 
Pérez Alonso, E. J., en Zugaldía Espinar, J. M. (dir.); Moreno-Torres HerreRA, M. R. (coord.), et al., Fundamentos de Derecho penal (parte general), Valencia, Tirant lo Blanch, 2010.

Rodríguez Devesa, J. M., y Serrano Gómez, A., Derecho penal español, 18. a ed. revisada y puesta al día, Madrid, Dykinson, 1995.

Rodríguez Mourullo, G., La omisión de socorro en el Código Penal, Madrid, Tecnos, 1966.

Rodríguez Mourullo, G., en Rodríguez Mourullo, G. (dir.); Barreiro, J. (coord.), et al., Comentarios al Código Penal, Madrid, Civitas, 1997.

Rodríguez Ramos, L., Compendio de Derecho penal (parte especial), 2." ed., Madrid, Trivium, 1987.

SÁinz Cantero, J. A., «El delito de omisión del deber de socorro», Revista General de Legislación y Jurisprudencia, núm. 209 (julio-diciembre de 1960).

Serrano Gómez, A., y Serrano Maíllo, A., Derecho penal, parte especial, 16. ${ }^{a}$ ed., Madrid, Dykinson, 2011.

Sola Reche, E., en Díez Ripollés, J. L., y Romeo Casabona, C. M., Comentarios al Código penal, parte especial, t. II, Títulos VII-XII y faltas correspondientes, Valencia, Tirant lo Blanch, 2004.

Suárez-Mira Rodríguez, C. (coord.), Judiel Prieto, A., y Piñol Rodríguez, J. R., Manual de Derecho penal, t. II, Parte especial, 6. ${ }^{a}$ ed., Pamplona, CivitasThomsom Reuters, 2011.

Torío López, A., «Aspectos de la omisión especial de socorro», en Anuario de Derecho Penal y Ciencias Penales, enero-agosto de 1967.

Varona Gómez, D., Derecho penal y solidaridad. Teoría y práctica del mandato penal de socorro, Madrid, Dykinson, 2005.

VVAA, «Una propuesta alternativa al sistema de penas y su ejecución, y a las medidas cautelares personales» (documentos), Grupo de Estudios de Política Criminal, 2005.

\section{JURISPRUDENCIA CITADA}

STS de 27 de abril de 1987, Sala 2. ${ }^{\text {a }}$ (Westlaw Aranzadi, RJ 1987/2623).

STS de 5 de diciembre de 1989, Sala 2. ${ }^{a}$ (Westlaw Aranzadi, RJ 1989/9426).

STS de 22 de febrero de 1992, Sala 2. (Westlaw Aranzadi, RJ 1992/1306).

STS de 26 de marzo de 1992, Sala 2. (Westlaw Aranzadi, RJ 1992/2480).

STS de 25 de junio de 1992, Sala 2. ' (Westlaw Aranzadi, RJ 1992/5884).

STS de 13 de octubre de 1992, Sala 2. (Westlaw Aranzadi, RJ 1992/8315).

STS de 25 de octubre de 1993, Sala 2. (Westlaw Aranzadi, RJ 1993/7956).

STS de 16 de mayo de 2002, Sala 2. (Iustel, § 330303 ).

STC 180/2004, de 2 de noviembre de 2004, Sala 1. ${ }^{\text {a }}$ (Westlaw Aranzadi, RJ 2004/180).

STS de 28 de enero de 2008, Sala 2. (Iustel § 275186). 